\title{
Intensive Follow-Up After Curative Surgery for Colorectal Cancer
}

\author{
Vigilância Intensiva do Carcinoma Colo-Rectal após \\ Tratamento de Intenção Curativa
}

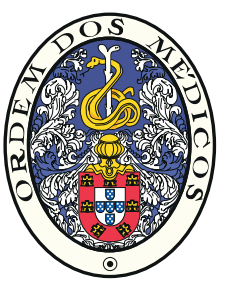

Rita Vale RODRIGUES $\rrbracket^{1}$, João Pereira da SILVA ${ }^{1}$, Isadora ROSA 1 , Isabel SANTOS ${ }^{1}$, Nuno PEREIRA ${ }^{1}$, Carla SOARES ${ }^{1}$, António Dias PEREIRA ${ }^{1}$

Acta Med Port 2017 Sep;30(9):633-641 - https://doi.org/10.20344/amp.7889

\section{ABSTRACT}

Introduction: The purpose of postoperative surveillance programs after curative treatment for colorectal cancer is to detect asymptomatic recurrences with the premise that an important rate will be eligible for curative resection, improving overall survival. We have implemented a surveillance program for patients with colorectal cancer, stages II-III, with periodic clinical, carcinoembryonic antigen and cancer antigen-19-9 assessment, computed tomography and colonoscopy. The aim of this study was to assess the rate of curative treatment of recurrence, colorectal cancer mortality and clinical characteristics associated with non-resectable recurrence. Material and Methods: Open cohort study, single center. All patients on the intensive surveillance program between March 2008 and January 2015 were included. Statistics: chi-square, Wilcoxon rank sum test, logistic regression, Kaplan-Meier log-rank test (SPSS20 ${ }^{\circledR}$ ). Results: We had a total 404 patients evaluated; $59.6 \%$ male; mean age of $65 \pm 10$ years; $50.7 \%$ rectal tumor; $56.2 \%$ stage III. The average time of follow-up was 37 months and the recurrence rate was $12.9 \%(n=52)$, mostly detected in the first three years $(88.4 \%)$. The pattern of recurrence was associated with the site of the primary tumor $(p<0.001)$. Twenty-one patients underwent curative resection. Factors associated with non-resectable recurrence were aged $\geq 70$ years $(p=0.022)$, disease location in the colon $(p=$ 0.033 ) and cancer antigen-19-9-9 elevation $(p=0.024)$. The overall rate of cancer-specific mortality was $2.2 \%(n=9)$.

Discussion: The association between colon cancer and non-resectable recurrence is explained by the higher rate of disseminated disease in these patients. Cancer antigen-19-9 added no benefit to the surveillance program.

Conclusion: This intensive real-world postoperative surveillance program allowed performing curative surgery to $40.3 \%$ of patients with recurrence.

Keywords: Continuity of Patient Care; Colorectal Neoplasms/surgery; Follow-Up Studies; Survival Analysis

\section{RESUMO}

Introdução: A vigilância intensiva pós-operatória do carcinoma colo-retal permite a deteção da recorrência em fase assintomática, aumentando o número de doentes que podem beneficiar de nova cirurgia. Implementámos um programa de vigilância de doentes com carcinoma colo-retal estádios II-III, operados com intenção curativa, com avaliação clínica, tomografia computorizada e colonoscopia. O presente estudo teve como objectivos avaliar a taxa de cirurgia de intenção curativa, a taxa de mortalidade por cancro e identificar características clínicas associadas à irresecabilidade da recidiva.

Material e Métodos: Estudo de coorte, unicêntrico. Foram incluídos todos os doentes com carcinoma colo-retal integrados em programa de vigilância entre março de 2008 e janeiro de 2015. Análise estatística: qui-quadrado, Wilcoxon, regressão logística, Kaplan-Meier (SPSS20 ${ }^{\circledR}$ ).

Resultados: Avaliámos 404 doentes; idade média: $65 \pm 10$ anos, 59,6\% sexo masculino, 50,7\% reto, 56,2\% estádio III. O tempo médio de vigilância foi 37 meses e a taxa de recidiva foi $12,9 \%(n=52)$, a maioria detetada nos primeiros três anos $(88,4 \%)$. 0 padrão de recidiva associou-se à localização do tumor primário $(p<0,001)$. Vinte e um doentes foram submetidos a cirurgia curativa. Os fatores associados a recidiva irressecável foram: idade $\geq 70$ anos $(p=0,022)$, carcinoma colo-retal localizado no cólon $(p=0,033)$ e elevação de antigénio carboidrato 19-9 $(p=0,024)$. A taxa global de mortalidade específica por cancro foi $2,2 \%(n=9)$.

Discussão: A associação entre neoplasia do cólon e recidiva irressecável deve-se à taxa mais elevada de doença disseminada nestes doentes. O antigénio carboidrato 19-9 não trouxe benefício acrescido ao programa de vigilância.

Conclusão: Este estudo confirma o interesse clínico da vigilância intensiva na deteção de recidiva assintomática, permitindo alcançar cirurgia curativa em $40,3 \%$ dos doentes com recidiva.

Palavras-chave: Análise de Sobrevida; Continuidade de Cuidados ao Doente; Neoplasias Colorrectais/cirurgia; Seguimento

\section{INTRODUCTION}

Colorectal cancer $(\mathrm{CRC})$ is one of the most common cancers in the world. The worldwide incidence of CRC is 17.2 per 100000 person-years. CRC is the third most incident cancer in men and the second most incident in women. ${ }^{1}$

Patients with CRC American Joint Committee on Cancer (AJCC) stage II or III are treated with curative-intent surgical resection and may also receive chemotherapy and/ or radiotherapy. Despite these treatments approximately $30 \%$ to $50 \%$ will have disease recurrence. ${ }^{2,3}$ About $90 \%$ of these recurrences present in the first 5 years after curative surgery, and most often in first three years after surgery. ${ }^{2-5}$

The purpose of postoperative surveillance programs after curative surgery for colorectal cancer (CRC) is to detect asymptomatic recurrences, and to identify new metachronous neoplasms at a preinvasive stage with the premise that an important rate will be eligible for curative resection, improving overall survival. ${ }^{6,7}$ So, as previously stated in the literature, fitness for eventual surgery and/or

1. Department of Gastroenterology. Instituto Português de Oncologia de Lisboa Francisco Gentil. Lisboa. Portugal.

$\triangle$ Autor correspondente: Rita Vale Rodrigues. rita.vale.rodrigues@gmail.com

Recebido: 26 de maio de 2016 - Aceite: 31 de julho de 2017 | Copyright @ Ordem dos Médicos 2017 
systemic therapy is a necessary condition for a surveillance program. ${ }^{8}$

Advantages of more intensive follow-up for patients treated for stage II and/or stage III disease have been demonstrated prospectively in several studies ${ }^{9-12}$ and in three meta-analyses of randomized controlled trials designed to compare low-intensity to high-intensity programs of surveillance. ${ }^{13-15}$ Given the variation in surveillance regimens noted in the literature, it is not surprising that guidelines regarding $C R C$ surveillance also vary considerably in their recommendations, although generically they all include periodic clinical evaluation, a carcinoembryonic antigen (CEA) assay and computed tomography. ${ }^{16-19}$

A prospective surveillance program with centralized nurse-led data collection was implemented at our institution in 2008; physically fit patients with surgically resected CRC, stages II and III were eligible. The aim of this study was to evaluate the rate of surgical treatment of recurrence with curative intent in our program; secondary outcomes were: colorectal cancer mortality, time to detection of recurrence, survival after treatment of recurrence with curative intent, evaluation of clinical characteristics associated with nonresectable recurrence and diagnostic accuracy of the surveillance model.

\section{MATERIAL AND METHODS}

In March 2008 we implemented a 5-year CRC surveillance program at Instituto Português de Oncologia de Lisboa Francisco Gentil, EPE (IPOLFG) coordinated by registered nurses and Gastroenterologists. A minimum dataset was devised and maintained prospectively to evaluate the clinical effectiveness of the surveillance program. After curative-intent surgery and eventual adjuvant chemotherapy, patients are enrolled in their first post-treatment visit.

This was a cohort, single-center study. We included all patients in the intensive surveillance program between $03 / 2008$ and $01 / 2015$, with at least one determination of any of the surveillance methods and a monitoring visit. Our institutional review committee approved the protocol. Patients provided informed consent for participation in this surveillance program.

\section{Surveillance protocol}

The surveillance program consists of periodic clinical assessment, CEA and cancer antigen 19-9 (CA 19-9) testing every three months for three years and then every six months for two more years, chest, abdominal and pelvic CTs once a year for the first three years and a follow-up colonoscopy within one year of surgery and then three years after (Table 1). A clinic nurse reviews the test results, and abnormal results are forwarded to the patient's attending physician for further management. The patients attend the clinic in person at least once a year to review test results and have a physical examination.

\section{Inclusion}

Patients aged 18 years or older were eligible for inclusion if they had a confirmed diagnosis of colorectal adenocarcinoma stage II or III and had, at the IPOLFG multidisciplinary team, been allocated for treatment with curative intent. All patients on the intensive surveillance protocol between March 2008 and January 2015, with at least one determination of any of the methods and a monitoring visit, were included.

\section{Exclusion}

Patients were excluded if they were treated with palliative intent (R1 or R2 resection), if they were older than 80 years or if they had significant comorbidities that would prevent curative treatment of recurrence. Patients were also excluded if they did not accept participation in the surveillance program or have a colorectal adenocarcinoma stage I or IV because they have a different follow-up program (only colonoscopy for stage I and tighter imaging surveillance for stage IV, coordinated by oncologists).

\section{Patient-related variables}

Data were collected regarding: patient demographics, tumor characteristics, local and/or systemic treatment history, initial clinical staging, dates and results of surveillance investigations (CEA and CA 19-9 tests, $\mathrm{CTs}$, and colonoscopies), recurrence demographics and management, and survival outcomes.

We considered rectal cancer all those that are located $\leq 15 \mathrm{~cm}$ from the anal verge; in case of disagreement between diagnostic tests, rigid proctoscopy was considered the gold standard.

Recurrences were classified as locoregional, including pelvic or perineal for rectal cancer, local lymph node or anastomotic or distant, including liver, lung, peritoneal and distant lymph node metastasis. If more than one

Table 1 - Colorectal cancer follow-up protocol

\begin{tabular}{|c|c|c|c|c|c|c|c|c|c|c|c|c|c|c|c|c|}
\hline $\begin{array}{r}\text { Months } \\
\text { after surgery }\end{array}$ & 3 & 6 & 9 & 12 & 15 & 18 & 21 & 24 & 27 & 30 & 33 & 36 & 42 & 48 & 54 & 60 \\
\hline Outpatient visit & $x$ & & & $x$ & & & & $x$ & & & & $x$ & & $x$ & & $\mathrm{x}$ \\
\hline CEA and CA-19-9 levels & $x$ & $x$ & $x$ & $x$ & $x$ & $x$ & $x$ & $x$ & $x$ & $x$ & $x$ & $x$ & $x$ & $x$ & $x$ & $\mathrm{x}$ \\
\hline Chest/abdomen/pelvis CT & & & & $\mathrm{x}$ & & & & $x$ & & & & $x$ & & & & \\
\hline Colonoscopy & & & & $\mathrm{x}$ & & & & & & & & & & $x$ & & \\
\hline
\end{tabular}

CEA: carcinoembryonic antigen; CA-19-9: cancer antigen 19-9; CT: computed tomography 
site of distant metastasis was detected, the patient was classified as having disseminated disease. In case of a symptom-driven diagnosis of recurrence, patients were classified as symptomatic. The following signs or symptoms were appreciated: change in bowel habits, abdominal or perineal pain, hematochezia, abdominal mass, palpable hepatomegaly, jaundice, anorexia or weight loss.

The result of the various examinations at the time of diagnosis or suspicion of recurrence was recorded and, thus, we were able to evaluate sensitivity and specificity.

Tumor markers were considered abnormal if increased above the superior reference value (CEA > $3 \mathrm{U} / \mathrm{mL}$ for non-smokers and > $5 \mathrm{U} / \mathrm{mL}$ for smokers and CA 19-9 > $37 \mathrm{U} / \mathrm{mL}$ ). Liver and lung recurrences were diagnosed by imaging. In the case of anastomotic, perineal or pelvic recurrence, biopsy for histological confirmation was carried out. Regarding to colonoscopy findings: low-risk adenoma refers to patients with tubular adenomas, $<10 \mathrm{~mm}$ in diameter and low-grade dysplasia; high-risk adenoma refers to patients with tubular adenoma $\geq 10 \mathrm{~mm}$, adenoma with villous histology, or high-grade dysplasia.

In patients undergoing surgery for relapse with a curative intent, the outcome was recorded, namely in the event of a second relapse and its treatment.

\section{Statistical analysis}

Descriptive statistical analysis was conducted to summarize baseline characteristics of the study population and separately for patients diagnosed with disease recurrence. Overall survival was measured from the date of diagnosis to the date of death due to any cause. Survival after recurrence was measured from the date of recurrence to the date of death due to any cause. Patients who were disease free or were alive at the last follow-up date were

Table 2 - Baseline characteristics of the study population $(n=404)$

\begin{tabular}{|c|c|}
\hline Characteristic & Patients No. (\%) \\
\hline \multicolumn{2}{|l|}{ Sex } \\
\hline Men & 241 (59.7) \\
\hline Women & $163(40.3)$ \\
\hline \multicolumn{2}{|l|}{ Tumor site } \\
\hline Rectum & $205(50.7)$ \\
\hline Colon & $199(49.3)$ \\
\hline \multicolumn{2}{|l|}{ Stage $\left(7^{\text {th }}\right.$ AJCC) } \\
\hline II & $177(43.8)$ \\
\hline III & $227(56.2)$ \\
\hline \multicolumn{2}{|l|}{ Initial treatment } \\
\hline \multicolumn{2}{|l|}{ Rectum } \\
\hline Neoadjuvant ChRT + surgery + adjuvant Ch & $169(82.4)$ \\
\hline Neoadjuvant ChRT or RT + surgery & $6(2.9)$ \\
\hline Surgery + adjuvant Ch /ChRT & $27(13.1)$ \\
\hline Surgery alone & $3(1.5)$ \\
\hline \multicolumn{2}{|l|}{ Colon } \\
\hline Surgery alone & $113(56.8)$ \\
\hline Surgery + adjuvant Ch & $86(43.2)$ \\
\hline \multicolumn{2}{|l|}{ Histological classification } \\
\hline Adenocarcinoma not otherwise specified & $364(90.1)$ \\
\hline Mucinous adenocarcinoma & $34(8.4)$ \\
\hline Serrated adenocarcinoma & $5(1.2)$ \\
\hline Choriocarcinoma-like & $1(0.3)$ \\
\hline Presence of lymphovascular invasion & $50(12.4)$ \\
\hline Presence of perineural invasion & $19(4.7)$ \\
\hline Presence of Crohn's like lymphoid reaction & $31(7.7)$ \\
\hline \multicolumn{2}{|l|}{ Pathological stage $(\mathrm{T})$} \\
\hline Pathologic complete response* & $55(13.6)$ \\
\hline $\mathrm{y}^{*} \mathrm{pT} 1$ & $14(3.5)$ \\
\hline $\mathrm{y}^{*} \mathrm{pT} 2$ & $67(16.6)$ \\
\hline $\mathrm{y}^{*} \mathrm{pT} 3$ & $243(60.1)$ \\
\hline $\mathrm{y}^{*} \mathrm{pT} 4 \mathrm{a}$ & $17(4.2)$ \\
\hline$y^{*} p T 4 b$ & $8(2)$ \\
\hline \multicolumn{2}{|l|}{ Pathological stage (N) } \\
\hline $\mathrm{y}^{*} \mathrm{pNO}$ & $264(65.3)$ \\
\hline $\mathrm{y}^{*} \mathrm{pN} 1$ & $107(26.5)$ \\
\hline $\mathrm{y}^{*} \mathrm{pN} 2$ & $33(8.2)$ \\
\hline \multicolumn{2}{|l|}{ Tumor regression grade* } \\
\hline Pathologic complete response & $55(31.4)$ \\
\hline Grade 1 & $70(40)$ \\
\hline Grade 2 & $39(22.3)$ \\
\hline Grade 3 & $11(6.3)$ \\
\hline
\end{tabular}

AJCC: American Joint Committee on Cancer; ChRT: chemoradiotherapy; Ch: chemotherapy; *only for rectal cancer after neoadjuvant therapy 
censored for the survival analysis.

Statistical analysis was performed with SPSS v20.0, using chi-square test, Wilcoxon rank sum test, a multivariate regression model and survival analysis with Kaplan-Meier log-rank test; $p$ value $<0.05$ was considered statistically significant.

\section{RESULTS}

\section{Baseline characteristics}

In total, 404 patients met inclusion criteria, with a mean age at diagnosis of 64.56 years $(25-80)$. The disease location was the rectum in $50.7 \%(n=205)$ and the colon in $49.3 \%(n=199)$. The clinical stage according to the $7^{\text {th }}$ AJCC classification was stage II in $43.8 \%(n=177)$ and stage III in $56.3 \%(n=227)$. Other important patient, treatment and disease baseline characteristics are shown in Table 2.

\section{Surveillance program}

After an average time of follow-up of 37 months (3 - 79) the recurrence rate was $12.9 \%(n=52)$, mostly detected in the first three years $(88.4 \%)$. Recurrence detection was due to elevation of tumor markers in $46.2 \%(n=24)$, CT in $40.4 \%(n=21)$, colonoscopy in $7.7 \%(n=4)$ and symptoms in $5.8 \%(n=3)$ of patients.

Among patients with recurrence, 18 had changes on surveillance $\mathrm{CT}$ alone, with the remaining relapse detection methods in the normal range; six showed only elevated CEA; and three had only elevated CA 19-9 - all these three patients showed disseminated disease when further studied. The accuracy of each tumor marker and CT in recurrence detection is described in Table 3.

Surveillance colonoscopy detected three local recurrences of rectal tumors, three synchronous tumors and two metachronous tumors. Surveillance colonoscopy also detected low-risk adenomas in 76 patients $(20.7 \%$ of those submitted to colonoscopy, $\mathrm{n}=367$ ) and high-risk adenomas in 22 patients $(5.9 \%$ of those submitted to colonoscopy, $\mathrm{n}=$ 367).

\section{Recurrence}

Characteristics of the 52 patients with documented tumor recurrence are outlined in Table 4 . There were $11.5 \%$ locoregional recurrences $(n=6)$ and $88.5 \%$ metastatic recurrences $(n=46)$.

Among the 29 patients with rectal tumors with recurrence, we registered 14 lung, six locoregional (three of them anastomotic,) four liver, one distant lymph node and one peritoneal recurrence; there were three cases of disseminated disease. Among the 23 patients with colonic cancer with recurrence we reported eight liver, three peritoneal, one distant lymph node, one lung and three distant recurrences with involvement of other organs (brain, soft tissue/skin); there were seven disseminated disease cases. The pattern of recurrence was significantly associated with the location of the primary tumor $(p<0.001)$, with liver and disseminated disease recurrences being more frequent in colonic tumors while lung and locoregional recurrences were more common in rectal tumors.

Twenty-one patients underwent curative resection (R0 resection): lung $(n=8)$, liver $(n=7)$, colon or rectum $(n=2)$, liver and colorectal $(n=1)$, brain $(n=1)$ and soft tissue $(n=$ 2) resections.

Patients in whom $\mathrm{R} 0$ resection was attempted but failed were considered palliative for further analysis.

\section{Survival}

A new relapse was detected in eight patients who underwent therapy with curative intent for their first recurrence (R0 resection); three of them were submitted to surgical treatment and only one is free of disease after the second relapse therapy with curative intent.

After recurrence the average time of follow-up was 15 months (1 - 49). Two-year survival was $95.2 \%$ if curative surgery was performed (R0 resection) versus $59.9 \%$ for non-resectable recurrence (Kaplan-Meier log-rank, $p=$ 0.016) (Fig. 1A).

The average overall survival was 56 months in patients with relapse who underwent a curative lung surgery $(n=$ 8 ) and 38 months in the group of patients submitted to a curative liver surgery after relapse $(n=8)$ (Wilcoxon rank sum test, $p=0.015$ ) without significant difference in time of recurrence compared to initial surgery.

The global 5-year survival for the study population was $94.3 \%$ (Fig. 1B). The overall rate of cancer-specific mortality was $2.2 \%(n=9)$.

\section{Factors associated with non-resectable recurrence}

The univariate and multivariate analysis of potential factors associated with non-resectable recurrence are documented in Tables 5 and 6, respectively. After multivariate analysis the only clinical factors associated with non-resectable recurrence were age $\geq 70$ years $(p=0.022)$, and colonic location of the tumor $(p=0.033)$; CA 19-9 elevation was the only altered surveillance test associated with non-resectable disease $(p=0.024)$ (Table 6).

Table 3 - Accuracy of tumor markers and CT in the detection of recurrence

\begin{tabular}{|c|c|c|c|}
\hline & CEA & CA $19-9$ & CT \\
\hline Sensitivity & $44.2 \%$ & $26.9 \%$ & $78.0 \%$ \\
\hline Specificity & $89.8 \%$ & $90.1 \%$ & $83.5 \%$ \\
\hline Positive predictive value & $39.0 \%$ & $28.6 \%$ & $44.3 \%$ \\
\hline Negative predictive value & $91.6 \%$ & $89.3 \%$ & $95.8 \%$ \\
\hline
\end{tabular}

CEA: carcinoembryonic antigen; CA-19-9: cancer antigen 19-9; CT: computed tomography 
Table 4 - Characteristics of patients with recurrence $(n=52)$

\begin{tabular}{|c|c|}
\hline Characteristic & Patients No. (\%) \\
\hline $\begin{array}{l}\text { Sex } \\
\text { Men } \\
\text { Women }\end{array}$ & $\begin{array}{l}32(61.5) \\
20(38.5)\end{array}$ \\
\hline Age & Mean $64(36-80)$ \\
\hline $\begin{array}{l}\text { Tumor site } \\
\text { Rectum } \\
\text { Colon }\end{array}$ & $\begin{array}{l}29(55.8) \\
23(44.2)\end{array}$ \\
\hline $\begin{array}{l}\text { Stage }\left(7^{\text {th }} A J C C\right) \\
\text { III }\end{array}$ & $\begin{array}{l}21(40.4) \\
31(59.6)\end{array}$ \\
\hline $\begin{array}{l}\text { Time of recurrence from curative surgery } \\
1 \\
2 \\
3 \\
4 \\
5\end{array}$ & $\begin{array}{c}9(17.3) \\
22(42.3) \\
15(28.8) \\
3(5.8) \\
3(5.8)\end{array}$ \\
\hline $\begin{array}{l}\text { Presentation at diagnosis of recurrence } \\
\text { Signs and symptoms } \\
\text { Altered CT } \\
\text { Elevated tumor markers (CEA or CA 19-9) } \\
\text { Altered colonoscopy }\end{array}$ & $\begin{aligned} & (5.8) \\
21 & (40.4) \\
24 & (46.2) \\
4 & (7.7)\end{aligned}$ \\
\hline $\begin{array}{l}\text { Site of recurrence } \\
\text { Locoregional } \\
\text { Lymph nodes } \\
\text { Peritoneum } \\
\text { Liver } \\
\text { Lungs } \\
>1 \text { site } \\
\text { Other }\end{array}$ & $\begin{aligned} 6 & (11.5) \\
2 & (3.8) \\
4 & (7.7) \\
12 & (23.1) \\
15 & (28.9) \\
10 & (19.2) \\
3 & (5.8)\end{aligned}$ \\
\hline $\begin{array}{l}\text { Treatment at recurrence } \\
\text { Palliative care } \\
\text { Palliative Ch } \\
\text { Liver resection } \\
\text { Lung resection } \\
\text { Colorectal resection } \\
\text { Other surgery } \\
\text { Multiple surgeries }\end{array}$ & $\begin{array}{c}9(17.3) \\
16(30.8) \\
8(15.4) \\
10(19.2) \\
4(7.7) \\
3(5.8) \\
2(3.8)\end{array}$ \\
\hline $\begin{array}{l}\text { Residual tumor factor }(\mathbf{n}=\mathbf{2 7}) \\
\text { R0 } \\
\text { R1 } \\
\text { R2 }\end{array}$ & $\begin{aligned} 21 & (40.4) \\
3 & (5.8) \\
3 & (5.8)\end{aligned}$ \\
\hline $\begin{array}{l}\text { Current status of patients with R0 resecti } \\
\text { Alive } \\
\text { Deceased } \\
\text { Alive and no evidence of disease }\end{array}$ & $\begin{aligned} 19 & (36.5) \\
2 & (3.8) \\
16 & (30.8)\end{aligned}$ \\
\hline $\begin{array}{l}\text { Current status of palliative patients } \\
\text { Alive } \\
\text { Deceased }\end{array}$ & $\begin{array}{c}24(46.2) \\
7(13.5)\end{array}$ \\
\hline
\end{tabular}

AJCC: American Joint Committee on Cancer; CT: computed tomography; Ch: chemotherapy; CEA: carcinoembryonic antigen; CA-19-9: cancer antigen 19-9

\section{DISCUSSION}

Disease recurrence occurred in less than a fifth of patients ( $n=52,12.9 \%$ of 404 patients), whereas previous studies report a recurrence rate of approximately $30 \%$ to $50 \%{ }^{2,3}$ Of note, the mean duration of surveillance was 37 months; therefore, it is possible that additional recurrences will be diagnosed with further follow-up.

The great majority of the patients had recurrence detected on the first three years after curative surgery $(88.4 \%)$, which is in agreement with previous literature, where a more intensive surveillance during the first three years is advocated. ${ }^{2-5}$ Nonetheless it is also known that surveillance for multi-modal-treated rectal cancers should continue beyond five years, as perioperative treatment might delay recurrence beyond this time point. ${ }^{20}$

Our study demonstrated that most recurrences were diagnosed by surveillance investigations $(n=49,94.2 \%$ of 52 patients). The initial abnormal surveillance test leading to the diagnosis of recurrence was an alteration of tumor markers (CEA or CA 19-9) in 24 patients, of CT imaging 
A

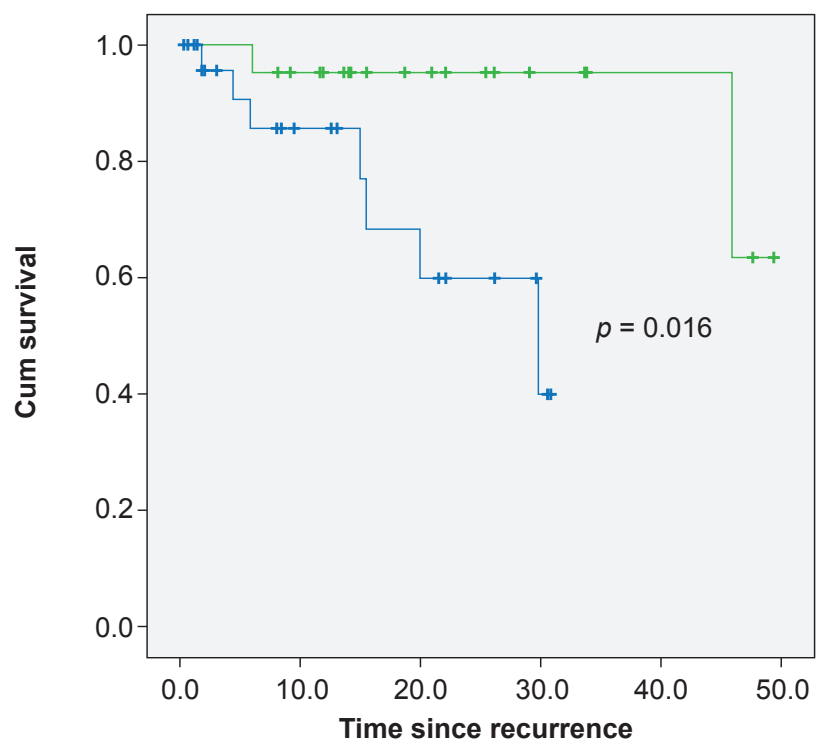

Release with curative surgery

$\neg$ No

$\neg$ Yes

+ No-censored

+ Yes-censored
B

\section{Survival functions}

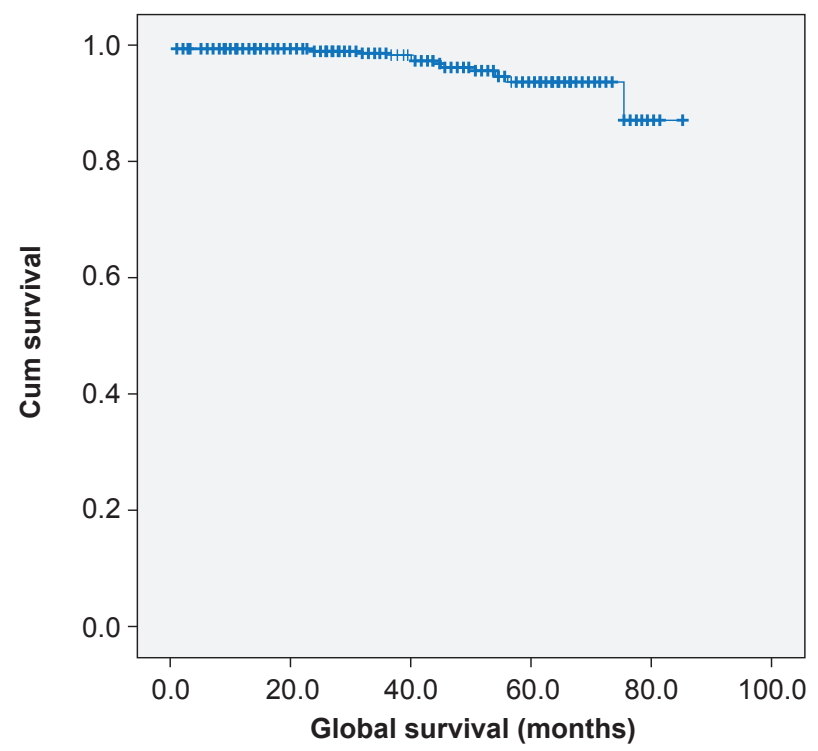

$\neg$ Survival function

+ Censored

Figure 1 - (A) Kaplan-Meier survival curve for patients with recurrence $(n=52)$ : curative surgery (R0 ressection) versus unresectable recurrence; (B) Kaplan-Meier overall survival curve for study population: patients with stage II to III colorectal cancer on intensive surveillance program $(n=404)$

in 21 patients, and of colonoscopy in four patients. The high negative predictive value of aggregate surveillance test reflects both the low prevalence of recurrence and the high aggregate sensitivity in recurrence diagnosis. CEA had a low positive predictive value, and there was a high false positive rate for a single isolated CEA level elevation, reinforcing the need for subsequent confirmation of further abnormal measurements before initiating imaging studies, as previously reported. ${ }^{21}$ Despite not being part of surveillance programs adopted by several international societies ${ }^{15-19}$ we decided to include the determination of CA 19-9 on our surveillance program based on a previous study carried out at our institution that showed an incremental benefit of the inclusion of this tumor marker on the diagnosis of recurrence. ${ }^{22}$ However, in our study, the patients whose recurrence was detected by an isolated elevation of CA 19-9 had advanced disseminated disease without the possibility of curative therapy, so we consider that there was no benefit from the inclusion of this tumor marker in the follow-up program.

Colonoscopy is an important component of surveillance and allows the detection of relapses with endoluminal expression, having a crucial role mainly in rectal tumors. However, it's major interest lies in the detection of metachronous adenomas and carcinomas during follow-

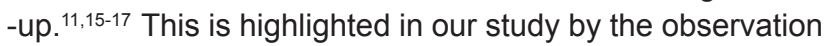
that new adenomas were diagnosed in more than one- quarter of patients who underwent surveillance colonoscopy ( $n=98,26.7 \%$ of 367 patients). Malignancy was diagnosed in $8(2.2 \%$ of 367 patients) with anastomotic recurrence in three of these patients $(1.5 \%$ of 205 patients with rectal cancer). Our data is in line with previous studies that found metachronous lesions in 1.5 to $3 \%$ of patients in the first three to five years postoperatively and local recurrence occurs in less than 5\% of patients with rectal cancer. ${ }^{23-34}$

Early detection of recurrence in the asymptomatic phase in most patients allowed curative intent treatment strategies for more than one third of patients ( $n=21,40.3 \%$ ). The pattern of recurrence was associated with the site of the primary tumor $(p<0.001)$. In rectal tumors we highlight pulmonary metastasis $(n=14)$ and locoregional relapse $(n=$ 6 ), including anastomotic. In colonic tumors the recurrence pattern favored liver metastasis $(n=8)$ and disseminated disease $(n=7)$. The higher rate of disseminated disease in colon cancer patients likely explains the association between colon cancer and non-resectable recurrence. These findings, like previous studies, suggest that developing approaches for adjusting the intensity of CRC surveillance tests based on primary tumor location may improve our ability to detect CRC recurrences at a more treatable stage. ${ }^{35}$ Probably personalized, risk stratified surveillance programs should be designed, like liver oriented surveillance for colonic cancer and lung oriented surveillance as well local oriented surveillance for rectal cancer. 
Table 5 - Univariate analysis of factors associated with non-resectable recurrence

\begin{tabular}{|c|c|c|c|}
\hline Characteristics & $\begin{array}{c}\text { Curative surgery } \\
\text { for recurrence }(n=21) \\
n(\%)\end{array}$ & $\begin{array}{c}\text { Non-resectable } \\
\text { recurrence }(n=31) \\
n(\%)\end{array}$ & $p$ value \\
\hline \multicolumn{4}{|l|}{ Clinical characteristic } \\
\hline \multicolumn{4}{|l|}{ Sex } \\
\hline Female & $6(28.6)$ & $14(45.2)$ & \multirow{2}{*}{$p=0.228$} \\
\hline Male & $15(71.4)$ & $17(54.8)$ & \\
\hline \multicolumn{4}{|l|}{ Age } \\
\hline$<70$ years & $17(81)$ & $16(51.6)$ & \multirow{2}{*}{$p=0.031$} \\
\hline$\geq 70$ years & $4(19)$ & $15(48.4)$ & \\
\hline \multicolumn{4}{|l|}{ Tumor site } \\
\hline Rectum & $15(71.4)$ & $14(45.2)$ & \multirow{2}{*}{$p=0.061$} \\
\hline Colon & $6(28.6)$ & $17(54.8)$ & \\
\hline \multicolumn{4}{|l|}{ Stage $\left(7^{\text {th }}\right.$ AJCC $)$} \\
\hline II & $10(47.6)$ & $11(35.5)$ & \multirow[b]{2}{*}{$p=0.382$} \\
\hline III & $11(52.4)$ & $20(64.5)$ & \\
\hline \multicolumn{4}{|l|}{ Histological classification } \\
\hline Adenocarcinoma not otherwise specified & $19(90.5)$ & $26(83.9)$ & \multirow{4}{*}{$p=0.494$} \\
\hline Mucinous adenocarcinoma & $2(9.5)$ & $5(16.1)$ & \\
\hline Serrated adenocarcinoma & $0(0)$ & $0(0)$ & \\
\hline Choriocarcinoma-like & $0(0)$ & $0(0)$ & \\
\hline \multicolumn{4}{|l|}{ Lymphovascular invasion } \\
\hline Yes & $3(14.3)$ & $5(16.1)$ & \\
\hline No & $18(85.7)$ & $26(83.9)$ & $p=0.857$ \\
\hline Perineural invasion & ) & & \\
\hline Yes & $4(19)$ & $2(6.5)$ & \\
\hline No & $17(81)$ & $29(93.5)$ & $p=0.201$ \\
\hline Crohn's like lymphoid reaction & & & \\
\hline Yes & $0(0)$ & $3(9.7)$ & \\
\hline No & $21(100)$ & $28(90.3)$ & $p=0.264$ \\
\hline Pathological stage (T) & & & \\
\hline Pathologic complete response ${ }^{*}$ & $3(14.3)$ & $1(3.2)$ & \\
\hline$y^{*} \mathrm{p} T 1$ & $0(0)$ & $0(0)$ & \\
\hline $\mathrm{y}^{*} \mathrm{pT} 2$ & $3(14.3)$ & $4(12.9)$ & \\
\hline$y^{*}$ pT3 & $12(57.1)$ & $23(74.2)$ & \\
\hline$y^{*}$ pT4a & $0(0)$ & $2(6.5)$ & $p=0.224$ \\
\hline$y^{*}$ pT4b & $3(14.3)$ & $1(3.2)$ & \\
\hline Pathological stage (N) & & & \\
\hline $\mathrm{y}^{*} \mathrm{pNO}$ & $15(71.4)$ & $16(51.6)$ & \\
\hline $\mathrm{y}^{*} \mathrm{pN} 1$ & $5(23.8)$ & $9(29)$ & $p=0.264$ \\
\hline $\mathrm{y}^{*} \mathrm{pN} 2$ & $1(4.8)$ & $6(19.4)$ & \\
\hline Tumor regression grade* & & & \\
\hline Pathologic complete response & $4(33.3)$ & $1(7.7)$ & \\
\hline Grade 1 & $2(16.7)$ & $7(53.8)$ & \\
\hline Grade 2 & $3(25)$ & $4(30.8)$ & $p=0.150$ \\
\hline Grade 3 & $3(25)$ & $1(7.7)$ & \\
\hline Adjuvant $\mathrm{Ch}$ & & & \\
\hline Yes & $4(19)$ & $13(41.9)$ & \\
\hline No & $17(81)$ & $18(58.1)$ & $p=0.084$ \\
\hline Recurrence site & & & \\
\hline Locoregional & $3(14.3)$ & $3(9.7)$ & \\
\hline Lymph nodes & $0(0)$ & $2(6.5)$ & \\
\hline Peritoneum & $0(0)$ & $4(12.9)$ & \\
\hline Liver & $7(33.3)$ & $5(16.1)$ & \\
\hline Lungs & $8(38.1)$ & $7(22.6)$ & $p=0.055$ \\
\hline$>1$ site & $1(4.8)$ & $9(29)$ & \\
\hline Other & $2(9.5)$ & $1(3.2)$ & \\
\hline Surveillance test & & & \\
\hline Presentation at diagnosis of recurrence & & & \\
\hline Signs and symptoms & $2(9.5)$ & $1(3.2)$ & \\
\hline Abnormal CT & $12(57.1)$ & $9(29)$ & \\
\hline Elevated tumor markers (CEA or CA 19-9) & $4(19)$ & $20(64.5)$ & $p=0.004$ \\
\hline Colonoscopy & $3(14.3)$ & $1(3.2)$ & \\
\hline CEA elevation & & & \\
\hline Yes & $6(28.6)$ & $17(54.8)$ & \\
\hline No & $15(71.4)$ & $14(45.2)$ & $p=0.061$ \\
\hline CA 19-9 elevation & & & \\
\hline Yes & $1(4.8)$ & $13(41.9)$ & \\
\hline No & $20(95.2)$ & $18(58.1)$ & $p=0.003$ \\
\hline Abnormal CT & & & \\
\hline Yes & $17(81)$ & $22(75.9)$ & $n=0741$ \\
\hline No & $4(19)$ & $7(24.1)$ & $p=0.141$ \\
\hline
\end{tabular}

AJCC: American Joint Committee on Cancer; Ch: chemotherapy; CT: computed tomography; CEA: carcinoembryonic antigen; CA-19-9: cancer antigen 19-9; *only rectal cancer 
Table 6 - Multivariate analysis of factors associated with non-resectable recurrence

\begin{tabular}{|c|c|c|}
\hline Clinical characteristic & & $p$ value \\
\hline Age $>70$ years & $\begin{array}{c}\text { RR } 5.43 \\
(95 \% \text { Cl: } 1.33-22.17)\end{array}$ & $p=0.018$ \\
\hline Site of disease - colon & $\begin{array}{c}\text { RR } 0.237 \\
(95 \% \text { Cl: } 0.064-0.873)\end{array}$ & $p=0.030$ \\
\hline \multicolumn{3}{|l|}{ Surveillance test } \\
\hline Diagnosis of recurrence by tumor markers & $\begin{array}{c}\text { RR } 0.1 \\
(95 \% \text { Cl: } 0.007-1.39)\end{array}$ & $p=0.086$ \\
\hline CEA elevation & $\begin{array}{c}\text { RR } 1.48 \\
(95 \% \text { Cl: } 0.25-8.78)\end{array}$ & $p=0.668$ \\
\hline CA 19-9 elevation & $\begin{array}{c}\text { RR } 13.8 \\
(95 \% \text { Cl: } 1.4-134.7)\end{array}$ & $p=0.024$ \\
\hline
\end{tabular}

We have shown that anatomical location of the primary CRC tumor and age $\geq 70$ years were independent predictors of non-resectable recurrence - the validation of these variables in prospective studies involving a large number of patients may assist in building models to target which patients should enter intensive follow-up strategies.

The limitations of the current study were the single center design and the lack of comparator arms, but otherwise it describes the results of a real-world surveillance program.

\section{CONCLUSION}

In conclusion, since the goal of this study was to demonstrate a clinical benefit (number of successful R0 resections) of intensive CRC surveillance, we assume that the objective was achieved as is demonstrated by the number of patients undergoing curative surgery for recurrence $(40.3 \%)$. Nevertheless, given the low rate of recurrences, the overall benefit applies to only $5 \%$ of the patients included in the surveillance program.

\section{ACKNOWLEDGMENTS}

The authors thank the other members of the Colorectal Cancer Multidisciplinary Group of IPOLFG who contributed to the clinical management of the patients: Manuel Limbert, Luís D’Orey, Rita Barroca, João Freire, Ana Luís, Ana Clara, Teresa Marques, Paula Pereira, Luisa Mirones, Gonçalo Fernandez, Catarina Travancinha, Ricardo Fonseca, Paula
Chaves, José Venâncio, Teresa Ferreira, Ana Gaspar, Elisabete Rosa.

\section{PROTECTION OF HUMANS AND ANIMALS}

This study was conducted in accordance with the principles of the Declaration of Helsinki, ICH Guidelines for Good Clinical Practice and in full conformity with relevant regulations. Patients provided written informed consent for study participation. The study protocol was approved by the local Ethics Committee.

\section{N. B.}

This manuscript has been previously presented as a poster at the United European Gastroenterology Week Barcelona 26-28 October 2015 and as a oral presentation at Semana Digestiva, Porto, 10-13 June 2015.

\section{DATA CONFIDENTIALITY}

The authors declare having followed the protocols in use at their working center regarding patients' data publication.

\section{CONFLICTS OF INTEREST}

All authors report no conflict of interest.

\section{FUNDING SOURCES}

None.

a practice guideline. BMC Cancer. 2003;3:26.

1. Ferlay J, Soerjomataram I, Ervik M, Dikshit R, Eser S, Mathers C, et al. GLOBOCAN 2012 v1.0, Cancer incidence and mortality worldwide: IARC CancerBase No. 11 [Internet]. Lyon, France: International Agency for Research on Cancer. [accessed 2015 Aug 29]. Available from http:// globocan.iarc.fr.

2. Böhm B, Schwenk W, Hucke HP, Stock W. Does methodic long-term follow-up affect survival after curative resection of colorectal carcinoma? Dis Colon Rectum. 1993;36:280-6.

3. Tjandra JJ, Chan MK. Follow-up after curative resection of colorectal cancer: a meta-analysis. Dis Colon Rectum. 2007;50:1783-99.

4. Kjeldsen BJ, Kronborg O, Fenger C, Jørgensen OD. The pattern of recurrent colorectal cancer in a prospective randomised study and the characteristics of diagnostic tests. Int J Colorectal Dis. 1997;12:329-34.

5. Figueredo A, Rumble RB, Maroun J, Earle CC, Cummungs B, McLeod $\mathrm{R}$, et al. Follow-up of patients with curatively resected colorectal cancer:
6. Taylor I. Quality of follow-up of the cancer patient affecting outcome. Surg Oncol Clin N Am. 2000;9:21-5.

7. Pita-Fernández $S$, Alhayek-Aí M, González-Martín C, López-Calviño $B$, Seoane-Pillado T, Pértega-Díaz S. Intensive followup strategies improve outcomes in nonmetastatic colorectal cancer patients after curative surgery: a systematic review and meta-analysis. Ann Oncol. 2015;26:644-56.

8. Meyerhardt JA, Mangu PB, Flynn PJ, Korde L, Loprinzi CL, Minsky BD, et al. Follow-up care, surveillance protocol, and secondary prevention measures for survivors of colorectal cancer: American Society of Clinical Oncology Clinical Practice Guideline Endorsement. J Clin Oncol. 2013;31:4465-70.

9. Pietra N, Sarli L, Costi R, Ouchemi C, Grattarola M, Peracchia A. Role of follow-up in management of local recurrences of colorectal cancer: a 
prospective, randomized study. Dis Colon Rectum. 1998;41:1127-33.

10. Rodriguez-Moranta F, Salo J, Arcusa A, Boadas J, Piñol V, Bessa $X$, et al. Postoperative surveillance in patients with colorectal cancer who have undergone curative resection: a prospective, multicenter, randomized, controlled trial. J Clin Oncol. 2006;24:386-93.

11. Secco GB, Fardelli R, Gianquinto D, Bonfante P, Baldi E, Ravera G, et al. Efficacy and cost of risk- adapted follow-up in patients after colorectal cancer surgery: a prospective, randomized and controlled trial. Eur J Surg Oncol. 2002;28:418-23.

12. Primrose JN, Perera R, Gray A, Rose P, Fuller A, Corkhill A, et al. Effect of 3 to 5 years of scheduled CEA and CT follow-up to detect recurrence of colorectal cancer: the FACS randomized clinical trial. JAMA. 2014;311:263-70.

13. Desch CE, Benson AB, Somerfield MR, Flynn PJ, Krause C, Loprinzi $\mathrm{CL}$, et al. Colorectal cancer surveillance: 2005 update of an American Society of Clinical Oncology Practice Guideline. J Clin Oncol. 2005;23:8512-9.

14. Jeffery M, Hickey BE, Hider PN. Follow-up strategies for patients treated for non-metastatic colorectal cancer. Cochrane Database Syst Rev. 2007;1:CD002200.

15. Renehan AG, Egger M, Saunders MP, O'Dwyer ST. Impact on survival of intensive follow up after curative resection for colorectal cancer: systematic review and meta-analysis of randomised trials. BMJ. 2002;324:813

16. NCCN Guidelines - Colon Cancer, Version 3.2015. [accessed 2015 Aug 28]. Available from: www.nccn.org.

17. NCCN Guidelines - Rectal Cancer, Version 3.2015. [accessed 2015 Aug 28]. Available from: http:www.nccn.org.

18. Schmoll HJ, Cutsem EV, Stein A, Valentini V, Glimelius B, Haustermans $\mathrm{K}$, et al. ESMO Consensus Guidelines for management of patients with colon and rectal cancer. A personalized approach to clinical decision making. Ann Oncol. 2012;23:2479-516.

19. Earle C, Annis R, Sussman J, Haynes AE, Vafaei A. Follow-up care, surveillance protocol, and secondary prevention measures for survivors of colorectal cancer. Program in Evidence-based Care (PEBC), Cancer Care Ontario Guidelines. Ontario: PEBC; 2012.

20. Guillem JG, Chessin DB, Cohen AM, Shia J, Mazumdar M, Enker W, et al. Long-term oncologic outcome following preoperative combined modality therapy and total mesorectal excisionof locally advanced rectal cancer. Ann Surg. 2005;241:829-36.

21. Litvak A, Cercek A, Segal N, Reidy-Lagunes D, Stadler ZK, Yaeger RD, et al. False-positive elevations of carcinoembryonic antigen in patients with a history of resected colorectal cancer. J Natl Compr Canc Netw. 2014;12:907-13.

22. Lage P, Fidalgo P, Claro I, Manoel L, Correia J, Nobre Leitão C, et al. Vigilância intensiva após cirurgia "curativa" de carcinoma do cólon e recto: impacto na ressecabilidade das recidivas e na sobrevivência. GE - J Port Gastrenterol. 1997;4:160-8.

23. Ringland CL, Arkenau HT, O'Connell DL, Ward RL. Second primary colorectal cancers (SPCRCs): experiences from a large Australian Cancer Registry. Ann Oncol. 2010;21:92.

24. Safi F, Beyer HG. The value of follow-up after curative surgery of colorectal carcinoma. Cancer Detect Prev. 1993;17:417.

25. Juhl G, Larson GM, Mullins R, Bond S, Polk HC Jr. Six-year results of annual colonoscopy after resection of colorectal cancer. World J Surg. 1990;14:255.

26. Green RJ, Metlay JP, Propert K, Catalano PJ, Macdonald JS, Mayer RJ, et al. Surveillance for second primary colorectal cancer after adjuvant chemotherapy: an analysis of Intergroup 0089. Ann Intern Med. 2002;136:261.

27. Mulder SA, Kranse R, Damhuis RA, Ouwendijk RJ, Kuipers EJ, van Leerdam ME. The incidence and risk factors of metachronous colorectal cancer: an indication for follow-up. Dis Colon Rectum. 2012;55:522.

28. Cali RL, Pitsch RM, Thorson AG, Watson P, Tapia P, Blatchford GJ, et al. Cumulative incidence of metachronous colorectal cancer. Dis Colon Rectum. 1993;36:388.

29. Liu L, Lemmens VE, De Hingh IH, de Vries E, Roukema JA, van Leerdam ME, et al. Second primary cancers in subsites of colon and rectum in patients with previous colorectal cancer. Dis Colon Rectum. 2013;56:158-68

30. Levi F, Randimbison L, Blanc-Moya R, Maspoli-Conconi M, Rosato V, Bosetti C, et al. High constant incidence of second primary colorectal cancer. Int J Cancer. 2013;132:1679-82.

31. Raj KP, Taylor TH, Wray C, Stamos MJ, Zell JA. Risk of second primary colorectal cancer among colorectal cancer cases: a population-based analysis. J Carcinog. 2011;10:6.

32. Kusters M, Marijnen CA, van de Velde CJ, Rutten HJ, Lahaye MJ, Kim $\mathrm{JH}$, et al. Patterns of local recurrence in rectal cancer: a study of the Dutch TME trial. Eur J Surg Oncol. 2010;36:470-6.

33. Taylor F, Quirke P, Heald RJ, Moran B, Blomqvist L, Swift I, et al. Preoperative high-resolution magnetic resonance imaging can identify good prognosis stage I, II, and III rectal cancer best managed by surgery alone. Ann Surg. 2011;253:711-9.

34. Young PE, Womeldorph CM, Johnson EK, Maykel JA, Brucher B Stojadinovic A, et al. Early detection of colorectal cancer recurrence in patients undergoing surgery with curative intent: current status and challenge. J Cancer. 2014;5:262-71.

35. Augestad KM, Bakaki PM, Rose J, Crawshaw BP, Lindsetmo RO, Dørum LM, et al. Metastatic spread pattern after curative colorectal cancer surgery. A retrospective, Iongitudinal analysis. Cancer Epidemiol. 2015;39:734-44 